\title{
Origin, Evolution, Breeding, and Omics of Chayote, an Important Cucurbitaceae Vegetable Crop
}

\author{
Yu-Ting Pu${ }^{1}$, Qing Luo ${ }^{2}$, Lin-Hong Wen ${ }^{2}$, Yu-Rong Li ${ }^{2}$, Ping-Hong Meng ${ }^{2}$, Xiao-Jing Wang ${ }^{1 *}$ \\ and Guo-Fei $\operatorname{Tan}^{2 *}$ \\ ${ }^{1}$ Key Laboratory of Plant Resource Conservation and Germplasm Innovation in Mountainous Region (Ministry of Education), \\ Guizhou University, Guiyang, China, ${ }^{2}$ Institute of Horticulture, Guizhou Academy of Agricultural Sciences, Guiyang, China
}

OPEN ACCESS

Edited by:

Alessandra Francini,

Sant' Anna School of Advanced

Studies, Italy

Reviewed by:

Noureddine Benkeblia,

University of the West Indies,

Jamaica

Umakanta Sarker,

Bangabandhu Sheikh Mujibur Rahman Agricultural University,

Bangladesh

Prashant Kaushik,

University of Valencia, Spain

*Correspondence:

Xiao-Jing Wang

xjwang8@gzu.edu.cn

Guo-Fei Tan

tagfei@foxmail.com

Specialty section:

This article was submitted to

Crop and Product Physiology,

a section of the journal

Frontiers in Plant Science

Received: 13 July 2021

Accepted: 23 August 2021

Published: 24 September 2021

Citation:

Pu Y-T, Luo Q, Wen L-H, Li Y-R, Meng $P-H$, Wang $X-J$ and Tan $G-F$ (2021) Origin, Evolution, Breeding, and Omics of Chayote, an Important

Cucurbitaceae Vegetable Crop.

Front. Plant Sci. 12:739091.

doi: 10.3389/fp/s.2021.739091
Chayote (Sechium edule), a member of the Cucurbitaceae family, is cultivated throughout tropical and subtropical regions of the world and utilized in pharmaceutical, cosmetic and food industries because it is an excellent source of minerals, dietary fibers, protein, vitamins, carotenoids, polysaccharides, phenolic and flavonoid compounds, and other nutrients. Chayote extracts process various medicinal properties, such as anticardiovascular, antidiabetic, antiobesity, antiulcer, and anticancer properties. With the rapid advancements of molecular biology and sequencing technology, studies on chayote have been carried out. Research advances, including molecular makers, breeding, genomic research, chemical composition, and pests and diseases, regarding chayote are reviewed in this paper. Future exploration and application trends are briefly described. This review provides a reference for basic and applied research on chayote, an important Cucurbitaceae vegetable crop.

Keywords: chayote, genetic breeding, genomic research, chemical composition, pests and diseases

\section{INTRODUCTION}

Sechium edule (Jacq.) Swartz (chayote; Figure 1), an herbaceous perennial climbing plant that belongs to the Cucurbitaceae family (Vieira et al., 2019; Ke et al., 2020), is cultivated in tropical and subtropical areas around the world (Bisognin, 2002; Riviello-Flores Luz et al., 2018). The S. edule plant has a tuberous rootstock and heart-shaped leaves (Shiga et al., 2015). $S$. edule is a monoecious plant with male flowers borne in clusters, and females occur singly (Abdelnour and Rocha, 2008; Chakravarty et al., 2019). Chayote fruit, as an important edible organ, has many nutrients needed by the body (Newstrom, 1991; Ruiz-López et al., 2010; Castro Rodríguez et al., 2015; Díaz-de-Cerio et al., 2019; Taynath et al., 2020; Sudargo et al., 2021). Moreover, other parts of S. edule plant, such as stems, tender leaves, and tuberous roots, are typically considered to be an important component of human diets (Jena et al., 2018; Vieira et al., 2019).

Chayote is rich in vitamins, proteins, polysaccharides, phenolic compounds, cucurbitacins. Chayote can also utilized in food, pharmaceutical, and cosmetic industries due to numerous health-promoting ingredients (Barba et al., 2014; Loizzo et al., 2016; Coronel et al., 2017; Rosado-Pérez et al., 2019). With the rapid advancements of molecular biology and sequencing technology, including genome sequencing, transcriptome sequencing, proteome sequencing, 


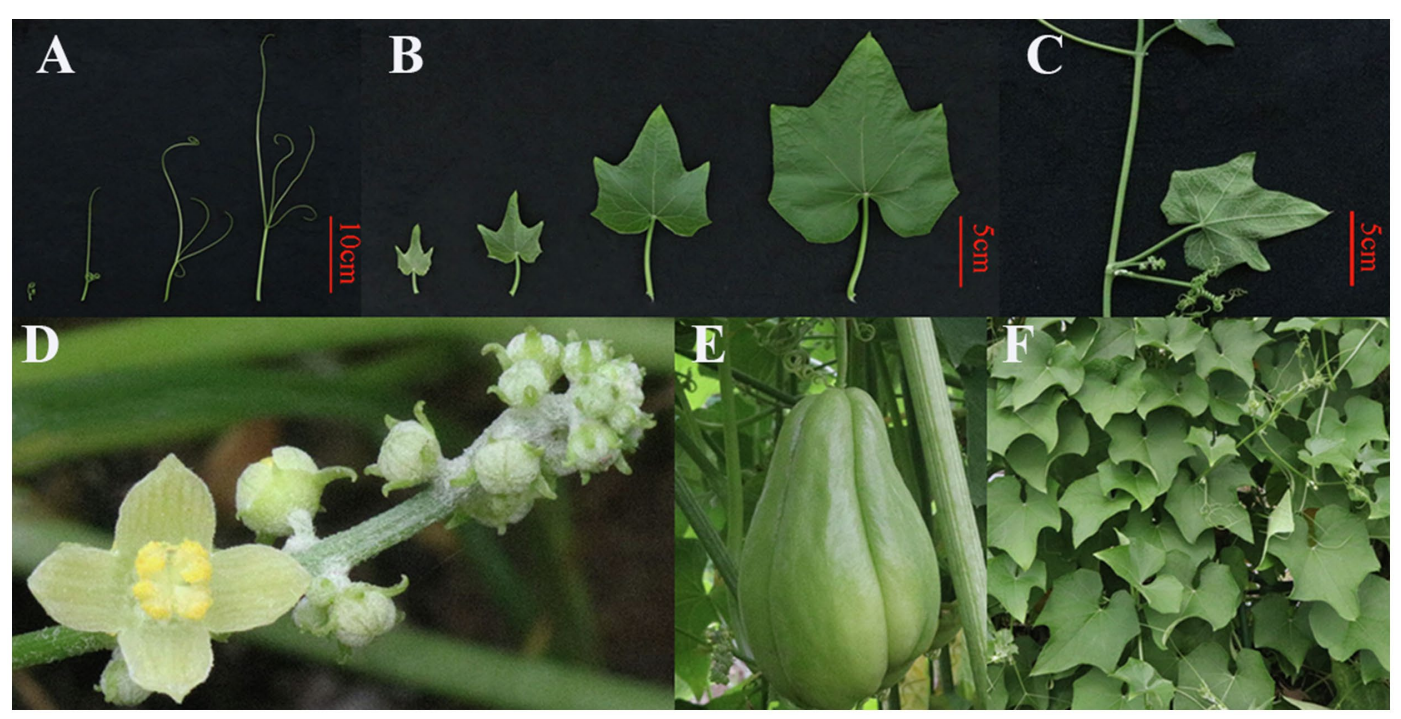

FIGURE 1 | The whiskers (A), leaves (B), stem (C), flowers (D), fruit (E), and plants (F) of the Sechium edule.

small RNA sequencing, and digital expression profile, large amount of data resource and research methods have been applied to study chayote plant. More and more attention has been attracted in exploring the molecular mechanisms of these health-promoting ingredients. However, so far, there is no available updated review that focuses on all aspects of this valuable vegetable. This prompted us to review the updated information of S. edule plant, including its origin and distribution, chemical composition, pests and diseases, breeding, omics research, and medicinal value, reported by previous studies.

\section{BIOLOGY AND ORIGIN}

\section{Biology}

The chayote plant (S. edule) is a perennial and monoecious climber with thickened roots, slender stems, and tendrils (Saade, 1996; Lim, 2012). The leaves of S. edule, located on sulcate petioles, are ovate-cordate to suborbicular and contain three to five separate tendrils, and the edges of leaves have minutely denticulate margins and contain three to five separate tendrils (Singh, 2007; Lim, 2012; Vieira et al., 2019). The flowers of $S$. edule are unisexual and contain both male and female reproductive units on the same plant (Quezada-Euán, 2018; Newstrom, 2019b). The clustered male flowers contain five stamens, which are distributed at intervals along the rachis. The female flowers are normally on the same axilla as the staminate flowers typically found singly (Chakravarty, 1990; Joshi et al., 2020). S. edule fruit developed from the ovary and grow singly on the plants. Fruit shape and size, as well as spine number and type on the fruit, vary in different varieties (Saade, 1996). Moreover, the skin of the smooth and prickly chayote also varies in color from yellowish-white to pale green to dark green (Cook, 1901; Newstrom, 1991; Moreira, 2015; Newstrom, 2019a). The seed is compressed and ovoid and contains soft and smooth testa (Singh, 2007).

\section{Origin}

The time frame and geographical location(s) of the S. edule plants remain unclear. Unlike other crops, there is no archaeological evidence to indicate how long $S$. edule has been cultivated. Previous studies revealed that the chayote originated from Mexico and Guatemala based on its concentrations of genetic diversity (Newstrom, 1991). However, Moreira, 2015 confirmed that Guatemala was not the place of origin of chayote based on the pan-etymological analysis. It is more likely that chayote was first cultivated or identified in the twelfth century BCE by Otomanguean speakers in southern Mexico (Moreira, 2015). Moreover, archaeological evidence supports the theory that the Mayans cultivated chayote as early as the eighth century. The closest morphological variants to chayote, known as the "wild" types of S. edule and Sechium chinantlense, are found in southern Mexico (Moreira, 2015). The chayote was introduced into the United States in the eighteenth century before its introduction to Europe and then Africa (Singh, 2007). During the same century, the chayote was introduced into southeast Asian countries (Saade, 1996). It was not introduced to China until the nineteenth century and is primarily distributed in all the provinces of southern China (Walters, 1989).

\section{NUTRITIONAL PROPERTIES}

All parts of $S$. edule plant can be consumed, including fruits, young leaves, shoots, and tuberous roots, and they primarily used for culinary purposes owing to their rich nutrients (Shiga et al., 2015; Sakung et al., 2020). A summary of the nutritional composition of the different edible parts of chayote is presented in Table 1. 


\section{Roots of S. edule}

The tuberized roots of $S$. edule, known as ichintal, are widely consumed in Latin America (Aung et al., 1990; Melo et al., 2006). These roots are generated after the first year of growth and contained a substantial amount of quality starch and fiber. Shiga et al. (2015) have shown that the concentration of starch in the tuberized roots of $S$. edule can be as high as $65 \%(\mathrm{w} / \mathrm{w}$; dry weight, DW). The cell wall structure of tuberized roots of $S$. edule is similar to those of potato, sweet potato, and cassava, which are mostly composed of high amounts of cellulose (92\% the fresh sample and $88 \%$ in cooked samples), hemicellulose, medium amounts of pectin, and a high amount of glucose $(47 \%)$. Therefore, the tuberized roots of $S$. edule are commonly used as an excellent substitute for the starch produced from potatoes and corn. In addition, the fresh tuberized roots of $S$. edule are an excellent resource of ascorbic acid (19 mg/100 g, DW) and phosphorus (34 mg/100g, DW; Shiga et al., 2015; Table 1).

\section{Seeds of S. edule}

The seeds of $S$. edule are composed of endocarp, endosperm, and cotyledons. The moisture content in mature seeds of $S$. edule differs from those of other crop seeds (Luna-Solano, 2018). The seeds of $S$. edule are rich in nutrients, such as proteins $(5.5 \mathrm{~g} / 100 \mathrm{~g}, \mathrm{DW})$, carbohydrates $(60 \mathrm{~g} / 100 \mathrm{~g}, \mathrm{DW})$, lipids $(0.4 \mathrm{~g} / 100 \mathrm{~g}, \mathrm{DW})$, and eight essential amino acids including leucine, arginine, phenylalanine, valine, lysine, isoleucine, threonine, and histidine (Vieira et al., 2019).

\section{Leaves and Stems of $\mathrm{S}$. edule}

The tender leaves and stems of cultivated $S$. edule are frequently consumed daily (Booth et al., 1992; Ordonez et al., 2006). The

TABLE 1 | Main nutrients of Sechium edule.

\begin{tabular}{|c|c|c|c|c|c|}
\hline Secondary metabolites & Roots & Stems & Leave & Fruits & Seeds \\
\hline Soluble sugars (g) & - & 0.30 & - & 1.66 & 4.20 \\
\hline Fiber (g) & 0.40 & 1.20 & - & 1.70 & - \\
\hline Lipids (g) & 0.20 & 0.40 & 2.32 & 0.13 & - \\
\hline $\begin{array}{l}\text { Nonpolar lipids (g/100 g } \\
\text { Lipid) }\end{array}$ & - & - & 40.2 & - & - \\
\hline $\begin{array}{l}\text { Phospholipids (g/100 g } \\
\text { Lipid) }\end{array}$ & - & - & 29.0 & - & - \\
\hline Proteins (g) & 2.00 & 4.00 & 2.69 & 0.82 & 5.50 \\
\hline $\begin{array}{l}\text { Amino acids (mg/g } \\
\text { Protein) }\end{array}$ & & & & Fruit & Seeds \\
\hline \multicolumn{6}{|l|}{ Protein) } \\
\hline Lysine & - & - & 5.93 & 0.42 & 1.53 \\
\hline Serine & - & - & 1.03 & 0.73 & 1.55 \\
\hline Glutamic acid & - & - & 12.15 & 1.97 & 5.25 \\
\hline Proline & - & - & 6.00 & 0.69 & 0.97 \\
\hline Glycine & - & - & 11.01 & 0.65 & 0.96 \\
\hline Alanine & - & - & 11.36 & 0.80 & 1.57 \\
\hline Cysteine & - & - & - & 0.04 & 0.10 \\
\hline Valine & - & - & 8.34 & 0.99 & 1.74 \\
\hline Methionine & - & - & 5.25 & - & 0.27 \\
\hline Isoleucine & - & - & 0.60 & 0.70 & 1.30 \\
\hline Leucine & - & - & 9.89 & 1.21 & 2.69 \\
\hline Tyrosine & - & - & 2.61 & 0.50 & 0.76 \\
\hline Phenylalanine & - & - & 5.10 & 0.75 & 1.81 \\
\hline Vitamins & & & & Fruit & \\
\hline Vitamin E (mg) & - & 90 & - & 0.12 & - \\
\hline Vitamin K $(\mu \mathrm{g})$ & - & - & - & 4.10 & - \\
\hline
\end{tabular}


tender leaves of $S$. edule contain a considerable amount of protein $(2.69 \sim 4.88 \mathrm{~g} / 100 \mathrm{~g}$ DW), pectin $(0.45 \mathrm{~g} / 100 \mathrm{~g}$ DW), lipids $(0.4 \sim 2.32 \mathrm{~g} / 100 \mathrm{~g}$, DW; Vieira et al., 2019). The main fatty acids include the linolenic (42.1-76.7\%), palmitic (13.7-38.5\%), and linoleic (5.7-15.3\%) acids, which are richly distributed in the tender leaves (Wijaya, 2013; Del Ángel-Coronel et al., 2018). The content of 13 amino acids (lysine, histidine, arginine, threonine, glutamic acid, proline, glycine, alanine, valine, methionine, leucine, tyrosine, and phenylalanine) in tender leaves was significantly higher than those in fruits and seeds (Wijaya, 2013). The stems of $S$. edule plant also contain dietary fiber (1.20 21.70\%), protein (4\%), niacin $(1.10 \mathrm{mg} / 100 \mathrm{~g}, \mathrm{DW})$, vitamin A (615 UI/100g, DW), and vitamins E (90 mg/100 g, DW). Thus, the tender vine is also widely consumed all around the world owing to its tenderness, flavor, short growth cycle, and rich nutrients (Chadha, 2009; Rohini et al., 2017).

\section{Fruit and Peels of S. edule}

Chayote fruit is an important part of the human diet (Dire et al., 2010). The contents of calories and lipids in chayote fruit $(19 \sim 31 \mathrm{kcal} / 100 \mathrm{~g}, \mathrm{DW}$ and $0.10 \sim 0.30 \mathrm{~g} / 100 \mathrm{~g}, \mathrm{DW}$, respectively) are relatively lower than those in the young stems $(60 \mathrm{kcal} / 100 \mathrm{~g}, \mathrm{DW}$ and $0.4 \mathrm{~g} / 100 \mathrm{~g}, \mathrm{DW}$, respectively) and tuberous root $(80 \mathrm{kcal} / 100 \mathrm{~g}, \mathrm{DW}$ and $0.20 \sim 0.33 \mathrm{~g} / 100 \mathrm{~g}$, DW, respectively). Chayote fruits are rich in complex carbohydrates, including dietary fiber $(0.40 \sim 7.60 \mathrm{~g} / 100 \mathrm{~g}$, DW) and starchy $(0.2 \sim 1.56 \mathrm{~g} / 100 \mathrm{~g}$, DW; Shiga et al., 2015). Moreover, the fiber content of chayote fruit is higher than that in tuberous roots, but lower than those in the stems and leaves, and the starch contents in chayote fruit are relatively lower than those in other organs (Shiga et al., 2015). Chayote fruits are rich in vitamin C $(7.7 \sim 20 \mathrm{mg} / 100 \mathrm{~g}, \mathrm{DW})$, vitamin $\mathrm{E}(0.12 \mathrm{mg} / 100 \mathrm{~g}$, DW), and folate (93 ug/100 g, DW; Fauziningtyas and Ristanto, 2020). In addition, the chayote fruit contains several minerals, including potassium $(125 \sim 338 \mathrm{mg} / 100 \mathrm{~g}, \mathrm{DW})$, calcium $(12 \sim 25 \mathrm{mg} / 100 \mathrm{~g}, \mathrm{DW})$, phosphorus $(4 \sim 60 \mathrm{mg} / 100 \mathrm{~g}$, DW), and magnesium $(12 \sim 15.4 \mathrm{mg} / 100 \mathrm{~g}, \mathrm{DW})$.

\section{BIOACTIVE COMPOUNDS AND FUNCTIONAL FOOD POTENTIAL}

\section{Sterols and Cucurbitacins}

Akihisa et al. (1986) determined the total sterol content in aerial sections $(16 \mathrm{mg} / 100 \mathrm{~g}, \mathrm{DW})$ and the pericarp $(38 \mathrm{mg} / 100 \mathrm{~g}$, DW) of $S$. edule plants purchased locally in Japan. Gas liquid chromatography technology was used to separate and identify 23 sterols and 14 triterpene alcohols from the sterol mixture (Akihisa et al., 1986). Cucurbitacins, as a group of tetracyclic triterpenoids, serve as heterologous chemical pheromones that protect the plants from external biological stress (Chen et al., 2012; Odeh et al., 2014; Chen, 2015). Previous studies demonstrated that numerous cucurbitacins obtained from natural sources exhibited potent cytotoxic activity and dramatically inhibited the growth and proliferation of cancer cells (Lan et al., 2013; Samuel, 2019; Shamran and Abed, 2020). To date, over 40 new cucurbitacins and their derivatives have been identified from the Cucurbitaceae crops and other plants (Riviello-Flores Luz et al., 2018). Cadena Iñiguez et al. (2011) identified several cucurbitacins from eight varieties of chayote, including $\mathrm{Cu}, \mathrm{B}, \mathrm{Cu}, \mathrm{E}, \mathrm{Cu}, \mathrm{P}$, and $\mathrm{Cu}$, glycosides, dihydrocucurbitacin, dihydroisocucurbitacin-I, glycocucur bitacin-I, dihydrocucurbitacin-D, isocucurbitacin-D, dihydroiso cucurbitacin-E, hydrocucurbitacin-E, isocucurbitacin-B, dihy droisocucurbitacin-B, cucurbitacin-L, cucurbitacin-E, and cucurbitacin-B. Previous studies revealed that the content of cucurbitacin in different varieties of chayote varied. The content of cucurbitacin in wild-type fruit $(1.456 \mathrm{mg} / \mathrm{g}$ fresh weight, FW) was higher than that in the commercial variety "Virens levis" $(0.116 \mathrm{mg} / \mathrm{g}, \mathrm{FW})$. Moreover, the yellow varieties contained low concentrations of cucurbitacins in comparison with the domesticated green varieties (Cadena Iñiguez et al., 2011).

\section{Polyphenol Compounds}

Polyphenolic compounds not only protect plants from diseases and insect attack, but also possess antiallergic, anti-inflammatory, antiviral, anticarcinogenic, and hypoglycemic properties (Kratchanova et al., 2010; Chun-Lin et al., 2012; Lattanzio, 2013). Siciliano et al. (2004) had reported that the content of anthraquinones, phenolic acids, coumarins, and flavonoids like anthocyanins was in the leaves $(0.35 \mathrm{~g} / 100 \mathrm{~g}, \mathrm{DW})$, followed by the roots $(0.31 \mathrm{~g} / 100 \mathrm{~g}, \mathrm{DW})$ and stems $(0.19 \mathrm{~g} / 100 \mathrm{~g}, \mathrm{DW})$. The content of apigenin 6-C- 3 -D-glucopyranosyl-8-C- $3-\mathrm{D}$ apiofuranoside and diosmetin $7-\mathrm{O}$-rutinoside $(0.133 \mathrm{~g} / 100 \mathrm{~g} \mathrm{DW}$ and $0.012 \mathrm{~g} / 100 \mathrm{~g}$ DW) was higher than those in the leaves and roots. The roots of $S$. edule contained the highest amount of vicenin-2 $(0.147 \mathrm{~g} / 100 \mathrm{~g}, \mathrm{DW})$ and vitexin $(0.151 \mathrm{~g} / 100 \mathrm{~g}$, $\mathrm{DW})$, and the leaves possess the highest amount of luteolin 7-O-rutinoside $(0.141 \mathrm{~g} / 100 \mathrm{~g}, \mathrm{DW})$, luteolin $7-O-\beta$-D-glucoside $(0.135 \mathrm{~g} / 100 \mathrm{~g}, \mathrm{DW})$ and apigenin $7-\mathrm{O}$-rutinoside $(0.018 \mathrm{~g} / 100 \mathrm{~g}$, DW). Ragasa et al. (2014) found that trans-cinnamic acid, phenylacetic acid, 3-octadecenoic acid, trilinolenin, and $\alpha$-linolenic acid are present in chayote leaves. Chao et al. (2014) revealed that the phenolic content in leaves of green chayote (0.262 g GAE/100g, DW; GAE: gallic acid equivalents) was higher than that in the leaves of yellow chayote $(0.063 \mathrm{~g}$ GAE/100g, DW). Moreover, Siciliano et al. (2004) observed that the relatively high content of flavonoids is widely distributed in the tuberized roots of $S$. edule $(0.31 \mathrm{~g} / 100 \mathrm{~g}, \mathrm{DW})$.

\section{Vitamins, Carotenoids, and Polysaccharides}

Chayote fruit is a much more impressive source of vitamins (Kumar et al., 2017; Fadliya et al., 2018; Daulay et al., 2021). Folate, also called vitamin B9, reduces the risk of birth defects of the brain and decreases the risk of preeclampsia and early labor (Fauziah et al., 2019; Purba et al., 2019; Fauziningtyas and Ristanto, 2020). The folate only exist in the fruits with high content, which was further determined before and after the cooking process $(93 \mathrm{ug} / 100 \mathrm{~g}, \mathrm{DW}$ and $18 \mathrm{ug} / 100 \mathrm{~g}, \mathrm{DW}$, respectively; Coronel et al., 2017). Vitamin A and vitamin E are also primarily distributed in chayote fruit, and they play 
important roles in maintaining good vision, reproductive health, healthy blood, and normal brain and skin (Vieira et al., 2019). A study reported that the stems of $S$. edule plants contain the highest content of vitamin A (615 Ul/100 g, DW) and vitamin E (90 mg/100 g, DW), followed by the fruit (vitamin A, $50 \mathrm{Ul} / 100 \mathrm{~g}$ DW and vitamin E, $4.7 \mathrm{mg} / 100 \mathrm{~g}, \mathrm{DW})$. Vitamin C is widely distributed in the fruit, peel, and leaves of $S$. edule, with the highest content in the peel $(51.6 \mathrm{mg} / 100 \mathrm{~g}$, DW), followed by the fruit $(5.5 \mathrm{mg} / 100 \mathrm{~g}, \mathrm{DW})$ and leaves $(4.6 \mathrm{mg} / 100 \mathrm{~g}, \mathrm{DW}$; Coronel et al., 2017).

Carotenoids are the most widely distributed pigments and naturally exhibit red, orange, and yellow colors. The type and content of carotenoids have been measured in different organs of the S. edule plant. Medina (2019) reported that the content of total carotenoids and $\beta$-carotene in the fruit peel was $1.7 \mathrm{mg} / 100 \mathrm{~g}$, DW and $0.36 \mathrm{mg} / 100 \mathrm{~g}$, DW, respectively. The content of lutein and $B$-carotene in the leaves $(7.4 \mathrm{mg} / 100 \mathrm{~g}$, FW and $4.4 \mathrm{mg} / 100 \mathrm{~g}, \mathrm{FW})$ was determined by Sriwichai et al. (2016).

Polysaccharides, as a long chain of carbohydrates, are used to provide structural support, store energy, and communicate signals, which include starch and non-starch polysaccharides (cellulose, gums, and hemicelluloses). The content of starch in chayote fruit is $0.2 \sim 1.56 \mathrm{~g} / 100 \mathrm{~g}$, DW, with the highest amount in chayote root $(13.6 \sim 72.8 \mathrm{~g} / 100 \mathrm{~g}$, DW), followed by seeds $(1.9 \mathrm{~g} / 100 \mathrm{~g}, \mathrm{DW})$ and stems $(0.7 \mathrm{~g} / 100 \mathrm{~g} \mathrm{DW})$. The content of non-starch polysaccharides in chayote fruit is $0.4 \sim 7.6 \mathrm{~g} / 100 \mathrm{~g}$, DW, with the highest amount in fruit peel $(45.2 \mathrm{~g} / 100 \mathrm{~g}, \mathrm{DW})$, followed by the stem $(21.7 \mathrm{~g} / 100 \mathrm{~g}, \mathrm{DW})$ and roots $(16 \mathrm{~g} / 100 \mathrm{~g}$, DW; Shiga et al., 2015).

Non-starch polysaccharides are comprised of water-soluble polysaccharides and water-insoluble polysaccharide. Shiga et al. (2015) indicated that the water-soluble polysaccharides in chayote fruit are composed of arabinose $(31 \sim 36 \mathrm{~mol} \%$. $1 \mathrm{~mol} \%=10,000 \mathrm{ppm})$, galactose $(31 \sim 35 \mathrm{~mol} \%)$, glucose $(11 \sim 15$ mol\%), galacturonic acid $(9 \sim 11 \mathrm{~mol} \%)$, and mannose ( $5 \sim 7 \mathrm{~mol} \%)$. In contrast, the water-insoluble polysaccharides in chayote fruits are mainly composed of galactose $(60 \mathrm{~mol} \%)$, and lesser amounts of arabinose $(11 \mathrm{~mol} \%)$, xylose $(7 \mathrm{~mol} \%)$, and glucuronic acid (7 mol\%).

\section{Pharmacological Properties}

Bioactive compounds can be divided into two groups: nutrients and nutraceuticals. Nutraceuticals, derived from "nutrition" and "pharmaceuticals," are non-nutritive plant chemicals with high antioxidant activity that sustain or promote health and have attracted the attention of the food and pharmaceutical industries (Meisel, 1997; Nasri et al., 2014; Santini and Novellino, 2017; Ghani et al., 2019). The effects of chayote on anti-cardiovascular diseases are primarily owing to its flavonoids (Juan et al., 2001; Lamuela-Raventos, 2005; García-Lafuente et al., 2009), which prevent atherosclerosis and fatty liver by reducing the contents of serum lipids and cholesterol (Meisel, 1997). Hydroalcoholic extracts of the root, pulp, and peel display antihypertensive activity owing to the presence of cinnamic acid methyl ester, coumaric acid, and vitexin (Vieira et al., 2019). The polysaccharides and phenolic composition, particularly flavonoids, play important roles in hypoglycemic effects (Elavarasan et al., 2016). The oral administration of chayote fruit juice was reported to promote the normalization of oral glucose tolerance ability and reduce oxidative stress (Mukherjee et al., 2013; Tiwari et al., 2013; Loizzo et al., 2016; Sangma et al., 2019).

Extracts of the shoots, including caffeic acid and hesperetin, increase the activity of amp-activated protein kinase and decrease the activities of lipogenic-related enzymes involved in the regulation of metabolism of hepatic lipids (Wu et al., 2014). Ordoñez et al. (2009) revealed that the increasing interest in the health benefits of flavonoids in S. edule was owing to its potent antioxidant and free radical scavenging abilities. Moreover, the bioactive polysaccharides in the $S$. edule plant, mostly represented by arabinans and homogalacturonans, have a high amount of antioxidant activity, which can modulate the functions of macrophages (Ordonez et al., 2006; Castro-Alves and Do Nascimento, 2016). Arabinogalactans, arabinoxylans, and glucuronoxylans in chayote pulp had a potent immunomodulatory effect (Classen et al., 2006; Duan et al., 2010), which was associated with their side-chains. For instance, type II arabinogalactan has an immunomodulatory effect associated with their branched structure. In addition, further analysis showed that crude chayote pectin has a cell protective effect (Shiga et al., 2015). The antiulcer activity of ethanolic extract of chayote fruit was owing to a reduction in total acidity and free acidity and an increase in the $\mathrm{pH}$ of gastric secretion (Sateesh et al., 2012). Six saponins isolated from the fruits and aerial parts of the $S$. edule plant demonstrated antiproliferative activity against MK-1, HeLa, and B16F10 tumor cells. Sechiumin protein, isolated from seed aqueous extracts, possesses the ability to inactivate ribosomes and has the potential of being chemotherapeutic (Ordoñez et al., 2009; Lim, 2012; Tamayo et al., 2016). Moreover, chayote fruit extracts have a positive impact on the treatment of acute myeloid leukemia, which also reduces the viability of cells and induces apoptosis (Aguiñiga-Sánchez et al., 2015). In addition, extracts of the chayote fruits were reported to inhibit the growth of pathogens, such as Escherichia coli, Klebsiella pneumoniae, Pseudomonas mirabilis, and Enterobacter cloacae (Ordoñez et al., 2003; Zampini et al., 2009). Although the pharmacological properties of $S$. edule plant were widely investigated and verified through in vitro and in vivo experiments, the molecular mechanism still remains unclear.

\section{Uses of S. edule}

All parts of the $S$. edule plants are useful. The fruits, young shoots, and tuberous roots are used as vegetables, and the leaves and fruits are also used as medicine. Moreover, the tuberous roots of $S$. edule can be used as a good substitute for potato, cassava, and wheat in diverse products (AilaSuárez et al., 2013), Moreover, the tuberous roots of S. edule can be used as a good substitute for potato, cassava, and wheat in diverse products (Shiga et al., 2015), sweets, and pickles (Nuwamanya et al., 2010). S. edule plants were also used as a traditional medicine to treat several diseases due to the presence of secondary metabolites (Aung et al., 1990; Lombardo-Earl et al., 2014). The fruits of S. edule are used 
for weight loss owing to their low calorie count and high amount of fiber, and the leaves are used to dissolve kidney stones (Jensen and Lai, 1986; Luna-Solano, 2018). Moreover, the $S$. edule plants are extensively utilized in the cosmetic and toiletry industries, including the production of skincare products, cosmetics, and pharmaceutical products (Wang et al., 2017). More recently, Metral et al. (2018) observed that chayote fruit extract protected keratinocytes against UVA-induced cytotoxicity and decreased the intracellular amounts of reactive oxygen species. In addition, Elavarasan et al. (2016) synthesized zinc oxide nanoparticles from the leaf extract that were significantly cytotoxic to MCF-7 breast cancer cells.

\section{BREEDING, BIOTECHNOLOGY AND BREEDING}

\section{Breeding}

Physical characteristics of the chayote fruit include its shape, size, surface texture, fruit color, and yields (Newstrom, 2019a). All of this would seem to point to the fact that this genus appears to have an enormous potential for genetic resources. However, the lack of knowledge in this field is primarily owing to the need for experimental materials. Efforts to conserve and study these resources have had less than satisfactory results. The endocarpic and precocious germination of the $S$. edule seed seriously hinders the breeding process. Commercial chayote varieties suffer from pests and diseases and a need to maintain fruit quality. Therefore, it is necessary to develop a breeding plan that takes these two aspects into consideration. So far, only written proposals associated with these two aspects have been issued. Newstrom (1986) recommended the development of two different breeding lines: unflavored fruits for industrial purposes and tasty fruits to use as vegetables. Aung et al. (1990) proposed to screen chayote varieties based on root characteristics, such as root length and starch content, associated with chayote types and their growth conditions, which were further used to evaluate wild species against some of the targets described above, particularly those related to disease resistance.

\section{Molecular Genetic Markers}

Molecular genetic markers are used to identify various genetic variations that link genetic traits to potential genomic variations (Domoney et al., 2006; Duran et al., 2009; Perezde-Castro et al., 2012). The development of different genetic markers and advancement in sequencing technologies has promoted the improvement of crops (Wani et al., 2007; Bhat et al., 2010; Hawkesford, 2012). Genetic markers are classified into classical markers, including morphological, cytological and biochemical markers, and DNA markers, such as RFLP, AFLP, SSRs, and SNP (Lewis et al., 2008; Wang et al., 2013). Genetic markers have also been applied in basic research on the utilization, and breeding of $S$. edule. In an effort to study the plant's genetic diversity and germplasm identification, 42 accessions of $S$. edule from Costa Rica were successfully characterized using isozyme markers (Vitomir et al., 2012). Joshi et al. (2020) classified 12 accessions of $S$. edule from on-farm and on-station into three categories using nine morphological and 20 RAPD markers. The genetic variation of 36 accessions of $S$. edule collected across 12 states in India was analyzed using directed amplification of minisatellite DNA (DAMD) technology and morphological traits (Jain et al., 2017). In addition, the genetic variations of 74 landraces of $S$. edule collected from the northeastern hill region of India were characterized using 28 RAPD and 30 ISSR markers (Verma et al., 2017). Thus, the molecular markers that have been developed represent a valuable resource to explore genetic linkage and gene localization.

\section{Tissue Culture}

Tissue culture, a simple and powerful technique, is used to generate plants in artificial media under aseptic and controlled environments. Plant tissue culture has rapidly become an essential techniques for plant breeding, including rapid clonal propagation, haploid techniques, embryo culture, somatic embryogenesis, synthetic seed production, and callus culture (Kyte et al., 2013). Cruz-Martínez et al. (2017) successfully regenerated plants by inducing them from axenic nodal segments, leaves, and petioles of $S$. edule plants. Abdelnour-Esquivel and Engelmann (2002) developed a micropropagation protocol from the shoots of $S$. edule, and the results showed that using the shoots as explants can induce the production of high percentages of callus. Moreover, the hypocotyl was also used as explants to develop an efficient plant regeneration system in the tissue cultures of $S$. edule.

Depending on the different purposes and materials, the type of hormones in different tissue cultures is different. Axillary shoots were induced from axenic nodal segments in MS media supplemented with $0.1 \mathrm{mg} / \mathrm{l}$ 6-benzylaminopurine (BA) (Katase, 1993; Masahiko, 1993). The leaf and petiole explants of $S$. edule were cultured on MS media supplemented with $0.1 \mathrm{mg} / \mathrm{l} \mathrm{BA}$ and $0.05 \mathrm{mg} / \mathrm{l}$ gibberellic acid (GA3; CruzMartinez et al., 2017). Callus from hypocotyls was induced on MS media with $0.1 \mathrm{mg} / \mathrm{l}$ indole acetic acid (IAA) and $1 \mathrm{mg} / 1$ 6-BA. Adventitious bud formation from calli was obtained in MS media with $0.5 \mathrm{mg} / \mathrm{l} \mathrm{IAA}$ and $0.5 \mathrm{mg} / \mathrm{l}$ 6-BA (Cruz-Martinez et al., 2017). GA3 plays an important role in promoting the elongation of regeneration buds (Amilineni et al., 2016). Moreover, different concentrations of auxin, IAA, and indole-3-butyric acid strongly induced the formation of roots from regenerated shoots.

Tissue culture of $S$. edule plant was first used to produce a considerable number of sterile seedlings to avoid using the fruit for sowing and reduce the cost. In addition, tissue culture is a powerful technique to study genetic transformations using Agrobacterium tumefaciens-mediated and particle bombardment methods. Although tissue culture systems of $S$. edule have been established, there are few reports on genetically modified S. edule plants. 


\section{NANOTECHNOLOGY}

The application of nanotechnology in plants has the potential to alter conventional crop production systems, enabling the controlled release of agrochemicals, e.g., fertilizers, pesticides, and herbicides, and target-specific delivery of biomolecules, e.g., nucleotides, proteins, and activators (Ocsoy et al., 2018; Fiol et al., 2021). The S. edule plant has a valuable role in other sustainable methods for nanotechnology. TerrazasHernandez et al. (2015) revealed that the cellulose nanocrystals enhanced the properties of cast films made of the tuber starch in S. edule plants. Moreover, chayote extracts have been used to synthesize stable silver nanoparticles based on their antioxidant properties (Bag et al., 2018).

\section{DISEASES AND PESTS}

As an important vegetable crop in the world, one of the main limiting factors in marketing is the losses of yield and quality caused by fungal diseases that range from 15 to $25 \%$ (Alvarado et al., 1989; Narayanasamy, 2006). The goal of this review is to summarize the pests, diseases, and corresponding symptoms during the growth and development of S. edule (Table 2). The chayote is attacked by different pathogenic fungi, particularly Ascochyta phaseolorum and several species of Fusarium, Macrophomina, and Colletotrichum. Merlín et al. (2007) identified five different pathogen fungal blisters caused by C. gloeosporioides, anthracnose caused by $C$. orbiculare, reddish-purple mold caused by F. oxysporum, white mold caused by Phytophthora capsici, and acid rot caused by Geotrichum sp. Treatment with hot water and chlorine $(1.5 \%)$ can effectively inhibit the occurrence and spread of diseases. Bezerra et al. (2016) reported that anthracnose on the fruits of $S$. edule plant was caused by Colletotrichum brevisporum, and further analysis found that the anthracnose occurred in all parts of the $S$. edule plant at any time during the growing season. Web blight, caused by Thanatephorus cucumeris, causes extensive leaf blight and webbing of the leaves, which were both associated with the presence of numerous microsclerotia on the dried leaves and petioles. Downy mildew disease caused by Pseudoperonospora cubensis on chayote was first reported in Taiwan (Ko et al., 2008). Chayote canker, caused by the bacterium Xanthomonas campestris, causes serious damage to the leaves of $S$. edule, which produces brown leaf spots surrounded by a yellow halo, and the central area of leaf spots often tear away during the late stage of canker disease (Dane et al., 1990). Chayote mosaic virus isolated from some accessions of $S$. edule in Costa Rica inhibits plant growth, produces deformed flowers, and decreases the amount of fruit set (Bernal et al., 2000). Alfalfa mosaic virus was found on chayote plants for the first time in Italy (Parrella et al., 2020).

A potential threat for the $S$. edule crop is also pests, such as whiteflies and thrips (Johari and Lukman, 2017). They can damage the leaves and cause plant death in severe cases. Chemical, biological control, and strengthened field management can effectively reduce the occurrence of pests.
TABLE 2 | Diseases and pests in S. edule.

\begin{tabular}{|c|c|c|}
\hline Biological diseases & Pathogen & Hazard site \\
\hline \multicolumn{3}{|l|}{ Fungal diseases } \\
\hline Leaf spot & $\begin{array}{l}\text { Pseudomonas syringae } \\
\text { pv. lachrymans }\end{array}$ & Leaf blade \\
\hline Downy mildew & Trichoderma cubans & Leaf blade \\
\hline Powdery mildew & $\begin{array}{l}\text { Ascomycetes and } \\
\text { Monocystis }\end{array}$ & $\begin{array}{l}\text { Leaf blade, petiole, stem, } \\
\text { fruit }\end{array}$ \\
\hline Vine wilt & $\begin{array}{l}\text { Microsporus of } \\
\text { watermelon shell, partly } \\
\text { known as Ascomycetes }\end{array}$ & Fruit, leaf, stem vine \\
\hline Anthrax & $\begin{array}{l}\text { Acanthopanax } \\
\text { senticosus from the } \\
\text { family A. semigeniculata }\end{array}$ & Leaf, stem, fruit \\
\hline Black Star Disease & Trichosporidium parvum & Leaf blade \\
\hline \multicolumn{3}{|l|}{ Bacterial diseases } \\
\hline Ulcerative disease & $\begin{array}{l}\text { The pathogen of the } \\
\text { disease is the bacteria of } \\
\text { the genus Rhizoma }\end{array}$ & Leaf blade \\
\hline Viral diseases & $\begin{array}{l}\text { CMV, CGMMV,WCMV, } \\
\text { SLCV }\end{array}$ & Leaf, fruit \\
\hline Mosaic virus & $\begin{array}{l}\text { SQMV, MLCV, MVBMV, } \\
\text { PMV, MWMV, WMV, } \\
\text { TMV, BYMV }\end{array}$ & Leaf, fruit \\
\hline Leaf spot & $\begin{array}{l}\text { CCSV, CLSV, MNSV, } \\
\text { WSMV, WLMV, ZYFV, } \\
\text { TRV, PRSV }\end{array}$ & Leaf, fruit \\
\hline \multicolumn{3}{|l|}{ Pests } \\
\hline Whitefly & Homoptera whitefly & Leaf, fruit \\
\hline Red Star & $\begin{array}{l}\text { Leaf acarites of the } \\
\text { genus Caryophyllaceae }\end{array}$ & Leaf blade \\
\hline Thrips & Insect species tassel & Leaf, fruit \\
\hline Aphids & General species & Leaf, fruit \\
\hline \multicolumn{3}{|c|}{ Non-biological diseases } \\
\hline Leaf fever & High temperature & Leaf blade \\
\hline
\end{tabular}

\section{OMICS RESEARCH}

Functional genomics is used to study how genes and intergenic regions of the genome contribute to different biological processes (Hieter and Boguski, 1997; Pevsner, 2015). With the advent of functional genomic research, the genome sequencing of the plants has been substantially accelerated, and a large amount of data has been generated (Morozova and Marra, 2008; Ondov et al., 2008). As an important squash vegetable, genomic, transcriptomic, and metabolomic analyses of the S. edule plant have been generated (Fu et al., 2021). A high-quality wholegenome sequence of $S$. edule with a size of $606.42 \mathrm{Mb}$ has been completed. The genome of $S$. edule is composed of 14 chromosomes and 28,237 predicted genes with 1,434 genes unique to $S$. edule. Moreover, $401.08 \mathrm{Mb}$ of repetitive sequences (65.94\% of the genome) were identified using an analysis of the genome database, structural predictions, and the long terminal repeats (LTRs) that comprised the highest proportion of repetitive sequences. Transcriptomics and metabolomics are used to investigate the sequence information and metabolite changes in different tissues/organs or the same tissues/organs at the different developmental stages. In 2021, the transcriptome and metabolome of the fruits at different developmental stages of $S$. edule were established, and the results revealed that the 
genes involved in fruit texture, pigment, flavor, flavonoids, antioxidants, and plant hormones are expressed at different levels during chayote fruit development (Fu et al., 2021). To our knowledge, this transcriptome and metabolome are the first ones reported for the $S$. edule plant. Moreover, immature seeds also contain phytohormones (gibberellin and auxin), which are responsible for the rapid growth of seeds and fruits (Albone et al., 1984; Roy, 2000).

\section{CONCLUSIONS AND FUTURE PERSPECTIVES}

Saccharum edule plant, as an important source of various nutrients and nutraceuticals, has the potential to be applied in the food, cosmetic, and pharmaceutical industries. With the increasing health consciousness, underutilized or neglected chayote crops have been studied more intensively owing to their rich nutraceuticals. However, many theoretical and technical problems persist in chayote research, including a lack of adequate germplasm resources, genetic breeding, and molecular biology. Future research should entail the collection of more germplasm resources of chayote and the establishment of efficient breeding platforms and systems. The whole-genome sequencing of chayote will contribute to an accurate understanding of the chayote genome. Re-sequencing can also accelerate the screening of germplasm resources, genetic evolution analyses, and the

\section{REFERENCES}

Abdelnour, A., and Rocha, O. J. (2008). Genetic characterization of a collection of chayote, Sechium edule (Jacq.) Swartz, in Costa Rica by using isozyme markers. Genet. Resour. Crop Ev. 55, 163-170. doi: 10.1007/s10722-007-9225-6

Abdelnour-Esquivel, A., and Engelmann, F. (2002). Cryopreservation of chayote (Sechium edule JACQ. SW.) zygotic embryos and shoot-tips from in vitro plantlets. CryoLetters 23, 299-308. doi: 10.1016/S1095-6433(02)00130-7

Aguiñiga-Sánchez, I., Soto-Hernánde, M., Cadena-Iñiguez, J., del Mar Ruíz-Posadas, L., Cadena-Zamudio, J. D., González-Ugarte, A. K., et al. (2015). Fruit extract from a Sechium edule hybrid induce apoptosis in Leukaemic cell lines but not in normal cells. Nutr. Cancer 67, 250-257. doi: 10.1080/01635581.2015.989370

Aila-Suárez, S., Palma-Rodríguez, H., Rodríguez-Hernández, A., Hernández-Uribe, J., Bello-Pérez, L., and Vargas-Torres, A. (2013). Characterization of films made with chayote tuber and potato starches blending with cellulose nanoparticles. Carbohyd. Polym. 98, 102-107. doi: 10.1016/j.carbpol.2013.05.022

Akihisa, T., Ghosh, P., Thakur, S., Rosentein, F. U., and Matsumoto, T. (1986). Sterol compositions of seeds and mature plants of family Cucurbitaceae. J. Am. Oil Chem. Soc. 63, 653-658. doi: 10.1007/BF02638231

Albone, K. S., Gaskin, P., Macmillan, J., and Sponsel, V. M. (1984). Identification and localization of gibberellins in maturing seeds of the cucurbit Sechium edule, and a comparison between this cucurbit and the legume Phaseolus coccineus. Planta 162, 560-565. doi: 10.1007/BF00399923

Alvarado, S., Saenz, M. V., and Valverde, E. (1989). Evaluación de tratamientos poscosecha para la preservación de los frutos de chayote (Sechium edule). Agron. Costarri. 13, 35-43.

Amilineni, U., Gangal, V., Gudasalamani, R., Karaba, N. N., and Ramanan, U. S. (2016). Establishment and standardization of in vitro regeneration protocol in Nothapodytes nimmoniana Graham and evaluation of camptothecine (CPT) in tissue culture plants. Ind. J.Plant Physiolo. 21, 1-7. doi: 10.1007/ s40502-015-0182-3 prediction of differential genes. Moreover, the study of expression patterns through chayote transcriptomes and proteomics should be conducted to reveal the functions of genes in chayote. With the development and application of molecular biology, research on active substances should focus on their synthesis and metabolic pathways, mechanisms of pathological regulation, and the popularization and application of research results.

\section{AUTHOR CONTRIBUTIONS}

X-JW, G-FT, Y-TP, L-HW, Y-RL, P-HM, and QL collected the manuscript data. X-JW, Y-TP, G-FT, QL, and L-HW wrote the manuscript. X-JW, G-FT, and P-HM approved the final manuscript. All authors have read and approved the final manuscript.

\section{FUNDING}

This study was financially supported by Guizhou Science and Technology Support Project [Qiankehe Support (2019) 2257]; Guizhou High Level Innovative Talents Training, Hundred Level Talents Project [Qiankehe talent (2015) 4024]; Guizhou Science and Technology Plan Project [Qiankehe Support (2021) 210]; and Guizhou Science and Technology Plan Project [Qiankehe Support (2021) 211].

Aung, L. H., Ball, A., and Kushad, M. (1990). Developmental and nutritional aspects of chayote (Sechium edule, Cucurbitaceae). Econ. Bot. 44, 157-164. doi: $10.1007 / \mathrm{BF} 02860483$

Bag, S. S., Banerjee, A., Singh, A., Goldar, A., and Bora, A. (2018). Green synthesis of silver nanoparticle using sechium edule aqueous extract and study of antimicrobial and catalytic activity. Curr. Nanomat. 3, 140-146. doi: 10.2174/2405461503666181002115659

Barba, F. J., Esteve, M. J., and Frígola, A. (2014). "Bioactive components from leaf vegetable products," in Studies in Natural Products Chemistry (Berlin: Elsevier), 321-346.

Bernal, J. J., Jiménez, I., Moreno, M., Hord, M., and Rodríguez-Cerezo, E. (2000). Chayote mosaic virus, a new Tymovirus infecting Cucurbitaceae. Phytopathology 90, 1098-1104. doi: 10.1094/PHYTO.2000.90.10.1098

Bezerra, J., Ferreira, P., Barbosa, L. D. F., Ramos-Sobrinho, R., Pinho, D., Reis, A., et al. (2016). First report of anthracnose on chayote fruits (Sechium edule) caused by colletotrichum brevisporum. Plant Dis. 100:217. doi: 10.1094/ PDIS-07-15-0793-PDN

Bhat, Z. A., Dhillon, W. S., Rashid, R., Bhat, J. A., Dar, W. A., and Ganaie, M. Y. (2010). The role of molecular markers in improvement of fruit crops. Notulae Sci. Biol. 2, 22-23. doi: 10.15835/nsb224222

Bisognin, D. A. (2002). Origin and evolution of cultivated cucurbits. Ciência Rural 32, 715-723. doi: 10.1590/S0103-84782002000400028

Booth, S., Bressani, R., and Johns, T. (1992). Nutrient content of selected indigenous leafy vegetables consumed by the Kekchi people of Alta Verapaz, Guatemala. J. Food Comp. Anal. 5, 25-34. doi: 10.1016/0889-1575(92)90005-5

Cadena Iñiguez, J., Soto Hernández, M., Arévalo Galarza, M., Avendaño Arrazate, C. H., Aguirre Medina, J. F., and Ruiz Posadas, L. D. M. (2011). Biochemical characterization of domesticated varieties of chayote Sechium edule (Jacq.) Sw. Fruits compared to wild relatives. Rev. Chapingo Ser. Hortic. 17, 45-55. doi: 10.5154/r.rchsh.2011.17.044

Castro Rodríguez, J., Toledo Díaz, A., Rodríguez Galdón, B., Perdomo Molina, A., Rodríguez-Rodríguez, E., and Díaz Romero, C. (2015). Morphological and 
chemical composition characterization of chayotas (Sechium edule) grown in the Canary Islands (Spain). Arch. Latinoam. Nutr. 65, 243-253.

Castro-Alves, V. C., and Do Nascimento, J. R. O. (2016). Polysaccharides from raw and cooked chayote modulate macrophage function. Food Res. Int. 81, 171-179. doi: 10.1016/j.foodres.2016.01.017

Chadha, M. L., Jaenicke, H., Ganry, J., Hoeschlezeledon, I., and Kahane, R. (2009). Indigenous vegetables of india with potentials for improving livelihood. Acta Hortic. 806, 579-585. doi: 10.17660/ActaHortic.2009.806.72

Chakravarty, H. L. (1990). Cucurbits of India and their role in the development of vegetable crops. Org. Proc. Res. Dev. 5, 426-433. doi: 10.1021/op010025y

Chakravarty, H., Bates, D. M., and Robinson, R. W. (2019). Cucurbits of India and their Role in the Development of Vegetable Crops. New York: Cornell University Press.

Chao, P. Y., Lin, S. Y., Lin, K. H., Liu, Y. F., Ju-Ing, H., Yang, C. M., et al. (2014). Antioxidant activity in extracts of 27 indigenous Taiwanese vegetables. Nutrients 6, 2115-2130. doi: 10.3390/nu6052115

Chen, X. (2015). An updated review of cucurbitacins and their biological and pharmacological activities. EXCLI J 14, 562-566. doi: 10.17179/excli2015-283

Chen, X., Bao, J., Guo, J., Ding, Q., Lu, J., Huang, M., and Wang, Y. (2012). Biological activities and potential molecular targets of cucurbitacins: a focus on cancer. Anti-Cancer Drug 23, 777-787. doi: 10.1097/ CAD.0b013e3283541384

Chun-Lin, K. E., Wang, D., Xie, H. W., Wang, Z. G., Chao-Tian, L. V., and Deng, Y. X. (2012). Research progress in antibacterial activity of polyphenol compounds. Sci. Tech. Food Ind. 17, 364-367. doi: 10.13386/j. issn1002-0306.2012.17.057

Classen, B., Thude, S., Blaschek, W., Wack, M., and Bodinet, C. (2006). Immunomodulatory effects of arabinogalactan-proteins from baptisia and echinacea. Phytomedicine 13, 688-694. doi: 10.1016/j.phymed.2005.10.004

Cook, O. F. (1901). The Chayote: A Tropical Vegetable. Washington: Govt. print. off.

Coronel, O., León-García, E., Vela-Gutiérrez, G., Medina Jdlc, G. V. R., and García, H. (2017). Chayote (Sechium Edule (Jacq.) Swartz). Fruit and Vegetable Phytochemicals: Chemistry and Human Health. 2nd Edn 979-992.

Cruz-Martinez, V., Castellanos-Hernandez, O. A., Acevedo-Hernandez, G. J., Torres-Moran, M. I., Gutierrez-Lomeli, M., Ruvalcaba-Ruiz, D., et al. (2017). Genetic fidelity assessment in plants of Sechium edule regenerated via organogenesis. S. Afr. J. Bot. 112, 118-122. doi: 10.1016/j. sajb.2017.05.020

Dane, F., Shaw, J., and Kloepper, J. W. (1990). Movement of genetically engineered xanthomonas campestris pv. Campestris in the environment. HortScience 25, 1131-1132. doi: 10.21273/HORTSCI.25.9.1131a

Daulay, A., Syahputra, R., and Nafitri, A. (2021). Antioxidant activity test of chayote (Sechium edule (Jacq.) Swartz) ethanol extract using DPPH method. J. Phys. 2021:e012035. doi: 10.1088/1742-6596/1819/1/012035

Del Ángel-Coronel, O. A., León-García, E., Vela-Gutiérrez, G., Rojas-Reyes, J. O., Gómez-Lim, M. Á., and García, H. S. (2018). Lipoxygenase activity associated to fruit ripening and senescence in chayote (Sechium edule Jacq. Sw. cv."virens levis"). J. Food Biochem. 42:e12438. doi: 10.1111/jfbc.12438

Díaz-de-Cerio, E., Verardo, V., Fernández-Gutiérrez, A., and Gómez-Caravaca, A. M. (2019). New insight into phenolic composition of chayote (Sechium edule (Jacq.) Sw.). Food chem. 295, 514-519. doi: 10.1016/j. foodchem.2019.05.146

Dire, G. F., Fernandes, J., Gomes, M. L., Albuquerque, A. C., Camacho, A., Cardoso, M., et al. (2010). Comparative analysis of the biological effects related to a natural extract processed from the bark of chayote (Sechium edule). Global Vet. 4, 225-229.

Domoney, C., Duc, G., Ellis, T. N., Ferrándiz, C., Firnhaber, C., Gallardo, K., et al. (2006). Genetic and genomic analysis of legume flowers and seeds. Curr. Opin. Plant Biol. 9, 133-141. doi: 10.1016/j.pbi.2006.01.014

Duan, J., Dong, Q., Kan, D., and Fa, N. J. (2010). Characterization of a pectic polysaccharide from the leaves of diospyros kaki and its modulating activity on lymphocyte proliferation. Biopolymers 93, 649-656. doi: 10.1002/ bip. 21430

Duran, C., Appleby, N., Edwards, D., and Batley, J. (2009). Molecular genetic markers: discovery, applications, data storage and visualisation. Curr. Bioinforma. 4, 16-27. doi: 10.2174/157489309787158198

Elavarasan, N., Kokila, K., Inbasekar, G., and Sujatha, V. (2016). Evaluation of photocatalytic activity, antibacterial and cytotoxic effects of green synthesized
$\mathrm{ZnO}$ nanoparticles by Sechium edule leaf extract. Res. Chem. Intermediat. 43, 1-16. doi: 10.1007/s11164-016-2830-2

Fadliya, F., Supriadi, S., and Diah, A. W. M. (2018). Analisis vitamin c dan protein pada biji buah labu siam (Sechium edule). Jurnal Akademika Kimia 7, 6-10. doi: 10.22487/j24775185.2018.v7.i1.10383

Fauziah, N. A., Hidajati, K., and Soejoenoes, A. (2019). The effect of chayote extract (Sechium edule) on blood pressure in pregnant women with hypertension. Indonesian J. Med. 4, 266-277. doi: 10.26911/theijmed. 2019.04.03.10

Fauziningtyas, R., and Ristanto, A. C. A. (2020). Effectiveness of consumption sechium edule on decreasing blood pressure in elderly with hypertension in coastal area. Earth Environ. Sci. 519:e012005. doi: $10.1088 / 1755-1315 / 519 / 1 / 012005$

Fiol, D. F., Terrile, M. C., Frik, J., Mesas, F. A., Álvarez, V. A., and Casalongué, C. A. (2021). Nanotechnology in plants: recent advances and challenges. J. Chem. Technol. Biotechnol. 96, 2095-2108. doi: 10.1002/jctb.6741

Fu, A., Wang, Q., Mu, J., Ma, L., Wen, C., Zhao, X., et al. (2021). Combined genomic, transcriptomic, and metabolomic analyses provide insights into chayote (Sechium edule) evolution and fruit development. Hortic. Res. 8, 1-15. doi: 10.1038/s41438-021-00487-1

García-Lafuente, A., Guillamón, E., Villares, A., Rostagno, M. A., and Martínez, J. (2009). Flavonoids as anti-inflammatory agents: implications in cancer and cardiovascular disease. Inflamm. Res. 58, 537-552. doi: 10.1007/ s00011-009-0037-3

Ghani, U., Naeem, M., Rafeeq, H., Imtiaz, U., Amjad, A., Ullah, S., et al. (2019). A novel approach towards nutraceuticals and biomedical applications. Scholars Int. J. Biochem. 2, 245-252. doi: 10.36348/SIJB.2019.v02i10.001

Hawkesford, M. J. (2012). The diversity of nitrogen use efficiency for wheat varieties and the potential for crop improvement. Better Crop Plant Food 96, 10-12.

Hieter, P., and Boguski, M. (1997). Functional genomics: it's all how you read it. Science 278, 601-602. doi: 10.1126/science.278.5338.601

Jain, J. R., Timsina, B., Satyan, K. B., and Manohar, S. H. (2017). A comparative assessment of morphological and molecular diversity among Sechium edule (Jacq.) Sw. accessions in India. 3 Biotech 7:e106. doi: 10.1007/ s13205-017-0726-5

Jena, A. K., Deuri, R., Sharma, P., and Singh, S. P. (2018). Underutilized vegetable crops and their importance. J. Pharmacog. Phytochem. 7, 402-407.

Jensen, L. P., and Lai, A. R. (1986). Chayote (Sechium edule) causing hypokalemia in pregnancy. Am. J. Obstet. Gynecol. 155, 1048-1049. doi: $10.1016 / 0002-9378(86) 90344-3$

Johari, A., and Lukman, A. (2017). The abundance of thrips (Thysanoptera) on vegetables plantation in Jambi region, Sumatera, Indonesia. J. Entomol. Res. 41, 25-32. doi: 10.5958/0974-4576.2017.00005.6

Joshi, B. K., Shrestha, S., Adhikri, B., and Bhattarai, M. (2020). Traditional practices and genetic diversity on chayote landraces and their conservation. Sustain. Dev. 10, 272-288. doi: 10.31924/nrsd.v10i2.060

Juan, D., Pérez-Vizcaíno, F., Jiménez, J., Tamargo, J., and Zarzuelo, A. (2001). Flavonoids and cardiovascular diseases. Stud. Nat. Prod. Chem. 25, 565-605. doi: 10.1016/S1572-5995(01)80018-1

Katase, M. (1993). Factors affecting proliferation of shoot in mulberry axillary bud culture. J. Sericult. Sci. Jpn. 62, 152-161. doi: 10.11416/ kontyushigen 1930.62 .152

Ke, J., Jiang, G., Shen, G., Wu, H., Liu, Y., and Zhang, Z. (2020). Optimization, characterization and rheological behavior study of pectin extracted from chayote (Sechium edule) using ultrasound assisted method. Int. J. Biol. Macromol. 147, 688-698. doi: 10.1016/j.ijbiomac.2020.01.055

Ko, Y., Chen, C., Liu, C. W., Chen, S., Maruthasalam, S., and Lin, C. (2008). First report of downy mildew caused by pseudoperonospora cubensis on chayote (Sechium edule) in Taiwan. Plant Dis. 92:1706. doi: 10.1094/ PDIS-92-12-1706C

Kratchanova, M., De Nev, P., Ciz, M., Lojek, A., and Mihailov, A. (2010). Evaluation of antioxidant activity of medicinal plants containing polyphenol compounds. Comparison of two extraction systems. Acta Biochim. Pol. 57, 229-234. doi: 10.1002/rhc3.24

Kumar, A., Islam, S., Dash, K. K., and Sarkar, S. (2017). Optimization of process parameters for osmotic dehydration of chayote cubes by response surface methodology. Int. J. Agr. Environ. Biotechnol. 10, 725-737. doi: 10.5958/2230-732X.2017.00090.0 
Kyte, L., Kleyn, J., Scoggins, H., and Bridgen, M. (2013). Plants From Test Tubes An Introduction to Micropropogation. Portland: Timber Press.

Lamuela-Raventos, R. M. (2005). Review: health effects of cocoa flavonoids. Food Sci. Technol. Int. 11, 159-176. doi: 10.1177/1082013205054498

Lan, T., Wang, L., Xu, Q., Liu, W., Jin, H., Mao, W., et al. (2013). Growth inhibitory effect of Cucurbitacin E on breast cancer cells. Int. J. Clin. Exp. Patho. 6, 1799-1805. doi: 10.1016/j.ejso.2013.07.084

Lattanzio, V. (2013). Phenolic Compounds: Introduction. Berlin: Springer.

Lewis, R. S., Nicholson, J. S., and Moon, H. S. (2008). Use of transferable Nicotiana tabacum L. microsatellite markers for investigating genetic diversity in the genus Nicotiana. Genome 51, 547-559. doi: 10.1139/G08-039

Lim, T. K. (2012). Sechium Edule. Edible Medicinal and Non-medicinal Plants. Berlin: Springer, 384-391.

Loizzo, M. R., Bonesi, M., Menichini, F., Tenuta, M. C., Leporini, M., and Tundis, R. (2016). Antioxidant and carbohydrate-hydrolysing enzymes potential of Sechium edule (Jacq.) Swartz (Cucurbitaceae) peel, leaves and pulp fresh and processed. Plant Food Hum. Nutr. 71, 381-387. doi: 10.1007/s11130-016-0571-4

Lombardo-Earl, G., Roman-Ramos, R., Zamilpa, A., Herrera-Ruiz, M., Rosas-Salgado, G., Tortoriello, J., et al. (2014). Extracts and fractions from edible roots of Sechium edule (Jacq.) Sw. with antihypertensive activity. EvidBased Compl. Alt. 2014:e594326. doi: 10.1155/2014/594326

Luna-Solano, G. (2018). "The drying and rehydration process of chayote (Sechium edule)" in 21st Int. Dry. Symp. 2018, 1107-1114.

Masahiko, K. (1993). Factors affecting proliferation of shoot in mulberry axillary bud culture. J. Sericultural Sci. Jpn. 62, 152-161. doi: 10.11416/ kontyushigen 1930.62 .152

Medina, T. D. S. (2019). Extração e caracterização por UPLC-MSE de compostos fenólicos obtidos de resíduos vegetais em serviços de alimentação. Ciência Rural 42, 2280-2287.

Meisel, H. (1997). Biochemical properties of bioactive peptides derived from milk proteins: potential nutraceuticals for food and pharmaceutical applications. Livest. Prod. Sci. 50, 125-138. doi: 10.1016/ S0301-6226(97)00083-3

Melo, E. D. A., Maciel, M. I. S., Lima, V. L. A. G., Leal, F. L. L., Caetano, A. C. D. S., and Nascimento, R. J. (2006). Antioxidant capacity of vegetables commonly consumed. Food Sci. Technol. 26, 639-644.

Merlín, K. J., Acosta-Ramosa, M., Cadena-Iñigueza, J., Avendaño-Arrazate, C., De Lourdes, M., and Arévalo-Galarza, M. V. H. (2007). Identification of postharvest chayote (Sechium edule) diseases in México. Proc. Interamer. Soc. Trop. Hort. 51, 217-224.

Metral, E., Rachidi, W., Damour, O., Demarne, F., and Bechetoille, N. (2018). Long-term genoprotection effect of sechium edule fruit extract against UVA irradiation in keratinocytes. Photochem. Photobiol. 94, 343-350. doi: 10.1111/ php. 12854

Moreira, F. A. (2015). Chayote: pre-columbian origins and dispersal. Hortic. Rev. 43, 89-143. doi: 10.1002/9781119107781.CH02

Morozova, O., and Marra, M. A. (2008). Applications of next-generation sequencing technologies in functional genomics. Genomics, 92, 255-264. doi: 10.1016/j.ygeno.2008.07.001

Mukherjee, P. K., Nema, N. K., Maity, N., and Sarkar, B. K. (2013). Phytochemical and therapeutic potential of cucumber. Fitoterapia 84, 227-236. doi: 10.1016/j. fitote.2012.10.003

Narayanasamy, P. (2006). Postharvest pathogens and disease management. Int. J. Food Sci. Technol. 42, 120-122.

Nasri, H., Baradaran, A., Shirzad, H., and Rafieian-Kopaei, M. (2014). New concepts in nutraceuticals as alternative for pharmaceuticals. Int. J. Prevent. Med. 5, 1487-1499.

Newstrom, L.E. (1986). Studies in the Origin and Evolution of Chayote, Sechium Edule (Jacq.) Sw. (Cucurbitaceae). Ph.D. Thesis, Berkeley: University of California.

Newstrom, L. E. (1991). Evidence for the origin of chayote, Sechium edule (Cucurbitaceae). Econ. Bot. 45, 410-428. doi: 10.1007/BF02887082

Newstrom, L. E. (2019a). 12 origin and evolution of chayote, Sechium edule. Biol. Utiliz. Cucurbitaceae 141-149. doi: 10.7591/9781501745447-014

Newstrom, L. E. (2019b). "Reproductive biology and evolution of the cultivated chayote Sechium edule: Cucurbitaceae" in The Evolutionary Ecology of Plants (Florida, FL: CRC Press), 491-509.

Nuwamanya, E., Baguma, Y., Emmambux, N., and Rubaihayo, P. (2010). Crystalline and pasting properties of cassava starch are influenced by its molecular properties. Afr. J. Food Sci. 4, 8-15.
Ocsoy, I., Tasdemir, D., Mazicioglu, S., and Tan, W. (2018). Nanotechnology in Plants. Plant Genetics and Molecular Biology. Cham: Springer, 263-275.

Odeh, F., Al-Jaber, H., and Khater, D. (2014). Nanoflora-how nanotechnology enhanced the use of active phytochemicals. Appl. Nanotechnol. Drug Deliv. 10:e58704. doi: 10.5772/58704

Ondov, B. D., Varadarajan, A., Passalacqua, K. D., and Bergman, N. H. (2008). Efficient mapping of applied biosystems SOLiD sequence data to a reference genome for functional genomic applications. Bioinformatics 24, 2776-2777. doi: 10.1093/bioinformatics/btn512

Ordoñez, A. A. L., Gómez, J. D., Cudmani, N. M., Vattuone, M. A., and Isla, M. I. (2003). Antimicrobial activity of nine extracts of Sechium edule (Jacq.) Swartz. Microbial Ecology in Health and Disease, 15, 33-39. doi: 10.1080/0891060010015583

Ordonez, A., Gomez, J., and Vattuone, M. (2006). Antioxidant activities of Sechium edule (Jacq.) Swartz extracts. Food Chem. 97, 452-458. doi: 10.1016/j. foodchem.2005.05.024

Ordoñez, A. A., Ordoñez, R. M., Zampini, I. C., and Isla, M. I. (2009). Design and quality control of a pharmaceutical formulation containing natural products with antibacterial, antifungal and antioxidant properties. Int. J. Pharm. 378, 51-58. doi: 10.1016/j.ijpharm.2009.05.040

Parrella, G., Troiano, E., Faure, C., Marais, A., and Candresse, T. (2020). First report of Alfalfa mosaic virus in chayote in Italy. Plant Dis. 105:el. doi: 10.1094/PDIS-10-20-2117-PDN

Pérez-de-Castro, A. M., Vilanova, S., Cañizares, J., Pascual, L., Blanca, J. M., Díez, M. J., et al. (2012). Application of genomic tools in plant breeding. Curr. Genomics 13, 179-195. doi: 10.2174/138920212800543084

Pevsner, J. (2009). Bioinformatics and functional genomics. Brief. Funct. Genomics Proteomics 2, 187-190. doi: 10.1002/9780470451496

Purba, J. N. P., Rusmarilin, H., and Lubis, Z. (2019). Microencapsulation of crude folic acid extract from chayote (Sechium edule Jacq. Swartz) with ionic gelation method. Indonesian Food Nutr. Prog. 16, 1-8. doi: 10.22146/ifnp.32520

Quezada-Euán, J. J. G. (2018). Stingless bees of mexico (the biology, management and conservation of an ancient heritage) $\|$ services provided by stingless bees. Springer, Cham. 167-192. doi: 10.1007/978-3-319-77785-6_7

Ragasa, C. Y., Biona, K., and Shen, C. C. (2014). Chemical constituents of Sechium edule (Jacq.) Swartz. Der Pharma Chemica 6, 251-255.

Riviello-Flores, M. D. L. L., Arévalo-Galarza, M., Lourdes, D., Cadena-Iñiguez, J., Soto-Hernández, R. M. et al (2018). Nutraceutic characteristics of the extracts and juice of chayote (Sechium edule (jacq.) sw.) fruits. Beverages 4:e37. doi: $10.3390 /$ beverages 4020037

Rohini, N., Shanmugasundaram, T., and Pandiarana, N. (2017). Review on underutilized vegetables for human health. Trend. Biosci. 10, 5593-5603.

Rosado-Pérez, J., Aguiñiga-Sánchez, I., Santiago-Osorio, E., and Mendoza-Núñez, V. M. (2019). Effect of Sechium edule var. nigrum spinosum (chayote) on oxidative stress and pro-inflammatory markers in older adults with metabolic syndrome: an exploratory study. Antioxidants 8:e146. doi: 10.3390/antiox8050146

Roy, S. (2000). "Studies on biology of sechium edule sw" in Darjeeling Hills: 1. Improvemnt of Crop Productivity 2. Survey of Animal Pest (Bangladesh: University of North Bengal).

Ruiz-López, I. I., Huerta-Mora, I. R., Vivar-Vera, M. A., Martínez-Sánchez, C. E., and Herman-Lara, E. (2010). Effect of osmotic dehydration on air-drying characteristics of chayote. Dry. Technol. 28, 1201-1212. doi: 10.1080/07373937.2010.482716

Saade, R. L. (1996). Chayote, Sechium edule (Jacq.). Sw. Biovers. Rome: IPK and IPGRI.

Sakung, J. M., Nurmayanti, Y., and Fitra, H. (2020). Nutritional evaluation of chayote flour-based biscuits (Sechium edule). Ind. J. Public Heal. Res. Dev. 11, 83-91.

Samuel, A. (2019). Cucurbitacins and its anticancer property: a review. Himalayan J. Health Sci. 44, 17-23. doi: 10.22270/hjhs.v4i4.46

Sangma, C., Kumar, V., Suri, S., Gat, Y., Kaushal, M., and Kumar, A. (2019). Preservation and evaluation of spiced chayote juice using hurdle technology. Braz. J. Food Technol. 22:e2018122. doi: 10.1590/1981-6723.12218

Santini, A., and Novellino, E. (2017). To nutraceuticals and back: rethinking a concept. Foods 6:e74. doi: 10.3390/foods6090074

Sateesh, G., Hussaini, S. F., Kumar, G. S., and Rao, B. (2012). Anti-ulcer activity of Sechium edule ethanolic fruit extract. Pharma Innov. 5, 77-81. 
Shamran, D. J., and Abed, E. H. (2020). Plants-derived materials and their effects as anticancer agents: a review. Ann. Trop. Med. Health 23, 77-86. doi: $10.36295 /$ ASRO.2020.23510

Shiga, T. M., Peroni-Okita, F. H. G., Carpita, N. C., Lajolo, F. M., and Cordenunsi, B. R. (2015). Polysaccharide composition of raw and cooked chayote (Sechium edule Sw.) fruits and tuberous roots. Carbohyd. Polym. 130, 155-165. doi: 10.1016/j.carbpol.2015.04.055

Siciliano, T., Tommasi, N., Morelli, I., and Braca, A. (2004). Study of flavonoids of Sechium edule (Jacq) Swartz (Cucurbitaceae) different edible organs by liquid chromatography photodiode array mass spectrometry. J. Agr. Food Chem. 52, 6510-6515. doi: 10.1021/jf040214q

Singh, D. (2007). 10 Cucurbits. Underutil. Underexp. Hort. Crop. 2:e175.

Sriwichai, W., Berger, J., Picq, C., and Avallone, S. (2016). Determining factors of lipophilic micronutrient bioaccessibility in several leafy vegetables. J. Agr. Food Chem. 64, 1695-1701. doi: 10.1021/acs.jafc.5b05364

Sudargo, T., Aulia, B., Prameswari, A. A., Isnansetyo, A., Puspita, I. D., and Budiyanti, S. A. (2021). Effect of administration of chaguro made of chayote (Sechium edule) and tuna (Thunnus sp.) on rats induced with streptozotocinnicotinamide and a high-fat diet. Curr. Res. Nutr. Food Sci. J. 9, 258-266. doi: 10.12944/CRNFSJ.9.1.24

Tamayo, J. F., Peña, G. R., De La Paz Lorente, C., Pacheco, C. H., and Campusano, Y. A. (2016). Sechium edule (jacq) sw: potencia fitoterapéutica como agente antibacteriano. MediSur 14, 664-670.

Taynath, S. J., Singh, B. K., Jena, S., and Said, P. P. (2020). Optimization of process variables for petha manufacture from chayote (Sechium edule Sw.). J. Food Process. Pres. 44:e14872. doi: 10.1111/jfpp.14872

Terrazas-Hernandez, J. A., Berrios, J. D. J., Glenn, G. M., Imam, S. H., Wood, D., Bello-Pérez, L. A., et al. (2015). Properties of cast films made of chayote (Sechium edule Sw.) tuber starch reinforced with cellulose nanocrystals. J. Polym. Environ. 23, 30-37. doi: 10.1007/s10924-014-0652-0

Tiwari, A. K., Kumar, D. A., Sweeya, P. S. R., Abhinay, K. M., Hanumantha, A. C., Lavanya, V., et al. (2013). Protein-tyrosine phosphatase $1 \mathrm{~b}$ inhibitory activity potential in vegetables' juice. Pharmacologia. 4, 311-319. doi: 10.5567/ pharmacologia.2013.311.319

Verma, V. K., Pandey, A., Jha, A. K., and Ngachan, S. V. (2017). Genetic characterization of chayote [Sechium edule (Jacq.) Swartz.] landraces of north Eastern Hills of India and conservation measure. Physiol. Mol. Biol. Plants 23, 911-924. doi: 10.1007/s12298-017-0478-Z

Vieira, E. F., Pinho, O., Ferreira, I. M., and Delerue-Matos, C. (2019). Chayote (Sechium edule): A review of nutritional composition, bioactivities and potential applications. Food Chem. 275, 557-568. doi: 10.1016/j. foodchem.2018.09.146
Vitomir, V., Milanko, S., Dragomir, L., and Ljuba, S̆. (2012). Some aspects of implementation DNA markers in animal breeding. Letopis Naunih Radova $36,101-108$.

Walters, T. W. (1989). Historical overview on domesticated plants in China with special emphasis on the Cucurbitaceae. Econ. Bot. 43, 297-313. doi: 10.1007/BF02858729

Wang, H.K., Shih, Y.J., and Chang, C.H. (2017). Chayote Fruit Cell Fluid, Preparation Method Thereof, Skincare and Wrinkle-Smoothing Composition Including the Same, and Method of Preparing Wrinkle-Smoothing Composition, New Taipei City, TW: Maxigen Biotech Inc., US 20170007534 A1.

Wang, Y. J., Wang, C. Y., Hong, Z., Hao, L., Liu, X. L., and Ji, W. Q. (2013). Genetic resources and crop evolution. Genet. Resour. Crop. 60, 115-117. doi: 10.1007/s10722-012-9907-6

Wani, S. N., Ahmad, M. F., and Malik, R. A. (2007). Genetic markers: a tool for genetic improvement in fruit crops. Prog. Hort. 39, 5-16.

Wijaya, C. H. (2013). Indonesian vegetables. Jakarta: Elex Media Komputindo.

Wu, C. H., Ou, T. T., Chang, C. H., Chang, X. Z., Yang, M. Y., and Wang, C. J. (2014). The polyphenol extract from Sechium edule shoots inhibits lipogenesis and stimulates lipolysis via activation of AMPK signals in HepG2 cells. J. Agr. Food Chem. 62, 750-759. doi: 10.1021/jf404611a

Zampini, I. C., Cuello, S., Alberto, M. R., OrdoEz, R. M., Almeida, R. D., and Solorzano, E. (2009). Antimicrobial activity of selected plant species from "the Argentine Puna" against sensitive and multi-resistant bacteria. J. Ethnopharmacol. 124, 490-505. doi: 10.1016/j.jep.2009.05.011

Conflict of Interest: The authors declare that the research was conducted in the absence of any commercial or financial relationships that could be construed as a potential conflict of interest.

Publisher's Note: All claims expressed in this article are solely those of the authors and do not necessarily represent those of their affiliated organizations, or those of the publisher, the editors and the reviewers. Any product that may be evaluated in this article, or claim that may be made by its manufacturer, is not guaranteed or endorsed by the publisher.

Copyright (C) $2021 \mathrm{Pu}, \mathrm{Luo}$, Wen, Li, Meng, Wang and Tan. This is an open-access article distributed under the terms of the Creative Commons Attribution License (CC BY). The use, distribution or reproduction in other forums is permitted, provided the original author(s) and the copyright owner(s) are credited and that the original publication in this journal is cited, in accordance with accepted academic practice. No use, distribution or reproduction is permitted which does not comply with these terms. 